\title{
Cuckoo Search Algorithm Application: Gas Pipeline Routing Selection Case Considering Peatlands and Conservation Area
}

\author{
Soufyan Maliki ${ }^{1 *}$, Farizal $^{1}$ \\ ${ }^{1}$ Department of Industrial Engineering, Universitas Indonesia, Depok, Indonesia \\ soufyan.maliki@ui.ac.id
}

\begin{abstract}
The purpose of the research is to optimize gas pipeline considering multiobjective, such as length, cost, area conservation, and population. Environmental data for peatland and conservation, which are impacted to the route selection, were referred to spatial data from reliable sources. Cost was calculated from estimated pipeline size. Cost approach were related to the inflation of the year. Population data were from Badan Pusat Statistik (BPS). After collecting the data, a software program was developed to solve the problem model. Validation of the program was done by running in lesser data. When the validity was considered good, the program was applied to the problem. Considering multi aspects, the result show the optimal solution. The cost is $33 \%$ higher than the shortest route, but the environmental aspect shows lower value. Total $\mathrm{CO}_{2}$ emission and conservation area which are impacted are 35\% and $72 \%$ lower respectively than the shortest route. Quantitative approach on environmental aspects (total emission $\mathrm{CO}_{2}$ and conservation area) and the social aspect (nearest population) can help decision maker to select the gas pipeline route.
\end{abstract}

Key words: Gas pipeline, route selection, optimal solution

\section{INTRODUCTION}

Transportation is required to deliver natural gas from the sources area (gas well) to the destination or users. It can be delivered as its natural form, as vapor. Another form of delivering natural gas is as liquid. When it is necessary to deliver gas from the source to the destination in the same land or island, pipeline is considered as the best option. Some papers mentioned studies in gas or oil pipeline route selection. [1] did a study in optimization objectives which included capital cost, consumption of energy when the facility is operated, maintenance and reparation cost, and the risk of the facility to the environment. Simulated annealing was applied to solve the problem. Route Optimization of submarine pipeline were examined by [2] using genetic algorithm, to solve multi objective case. [3] assessed two phase flow fluid when optimizing pipeline route. General genetic algorithm (gGA) and steady state genetic algorithm were used to solve the automatic route model. [4] did as study on pipeline route for ore concentrate which the fluid state is slurry. On the study, two algorithms were compared, Ant Colony optimization and Dijkstra algorithm. [5] compared two methods of pipeline route selection by using Dijkstra least cost path (LCP) and Laplacian smoothing algorithm. [6] used other types of method, they are simple additive weighting (SAW), analytic hierarchy process (AHP), and technique for order preference by similarity to ideal solution (TOPSIS) to solve spatial multicriteria decision making of gas pipeline routing.

When the pipeline route will be determined, many aspects should be considered [7], such as: (1) cost efficiency, (2) pipeline integrity, (3) impact to environment, (4) public security, (5) land use limitation, and proximity to the facility.Every location where the pipeline will be installed has the different landscape and condition. It may relate to the climate of the location. The area near pole is different with the area in the equator. The area in the desert is different from the area in the tropical area which has heavy rainfall. Beside the difficulty of construction, the sustainability aspects should be in the mind of pipeline project decision maker. Decision maker should achieve minimum impact to environment whenever the impact cannot be avoided.

In this paper, we would like to include environmental factor which has major role in balance of ecosystem in the tropical land area, they are tropical peatland and conservation area. We found it is still rare, where a study includes these aspects. Why peatland is an important ecosystem has been analyzed in many papers. For only, $12 \%$ of peatland area globally, tropical peatland holds more than $20 \%$ of peatland carbon stock globally [8]. The contribution of $\mathrm{CO}_{2}$ emission due to function degradation of peatland in South East Asia is about 1.3\% to 3.1\% of current global $\mathrm{CO}_{2}$ emission from fossil fuel combustion [9]. The effect of disturbing the peatland, some amount of $\mathrm{CO}_{2}$ will be emitted to atmosphere. In tropical countries, many regions are now set as conservation zone by the government. The conservation areas conserve the local and special animals andvegetations which are basically prohibited to disturb. Gas pipeline route selection in Kalimantan, Indonesia is focused as a case to be studied in this paper. Kalimantan has important tropical peatland and several conservation areas.

Since there are multi objectives want to be achieved, we should develop mathematical model which represents those 
Soufyan Maliki et al., International Journal of Emerging Trends in Engineering Research, 8(9), September 2020, 5598 - 5602

purpose. One of model usually developed in this case is goal programming. Goal programming purpose is to find solution which is a tradeoff many objectives. There are many kinds of goal programming model. Two type are well known are pre-emptive (lexicographic) goal programming and weighting goal programming. Lexicographic goal programming will be used to find solution among several defined criterions in pipeline route selection.

The aim of this study is to understand the effect of two major environment aspects, i.e. total $\mathrm{CO}_{2}$ emission due to peatland intervention and how much conservation area will be impacted in gas pipeline route selection. As per literature study, the use of goal programming in gas pipeline route selection still less. In this study, it is expected to have better understanding in using goal programming to solve the route selection case [20-21].

Supply and demand projections by Indonesia Ministry of Energy and Mineral Resources for 2018-2027 are indicated in Table 1 and Table 2 respectively.

Table 1:Supply projection of natural gas in Kalimantan.

(Source: Neraca Gas Bumi Indonesia 2018-2027)

\begin{tabular}{ccccc}
\hline Year & $\begin{array}{c}\text { Total } \\
\text { Existing } \\
\text { Supply }\end{array}$ & $\begin{array}{c}\text { Total } \\
\text { Project } \\
\text { Supply }\end{array}$ & $\begin{array}{c}\text { Total } \\
\text { Potential } \\
\text { Supply }\end{array}$ & Total Supply \\
\hline 2018 & 1967,23 & 26,91 & 0,00 & 1994,14 \\
2019 & 2063,65 & 88,28 & 0,00 & 2151,93 \\
2020 & 1984,57 & 90,78 & 0,00 & 2075,35 \\
2021 & 1867,06 & 237,30 & 0,00 & 2104,36 \\
2022 & 1728,71 & 476,70 & 1,69 & 2207,10 \\
2023 & 1535,68 & 825,22 & 2,40 & 2363,30 \\
2024 & 1388,09 & 1218,20 & 0,20 & 2606,49 \\
2025 & 1237,58 & 1184,46 & 12,00 & 2434,04 \\
2026 & 1101,77 & 1122,91 & 25,89 & 2250,57 \\
2027 & 950,70 & 1086,81 & 49,60 & 2087,11 \\
\hline
\end{tabular}

Table 2: Supply projection of natural gas in Kalimantan.

(Source: Neraca Gas Bumi Indonesia 2018-2027)

\begin{tabular}{|c|c|c|c|c|c|c|c|}
\hline Year & $\begin{array}{l}\text { Crude Oil } \\
\text { Lifting }\end{array}$ & $\begin{array}{c}\text { Government } \\
\text { Program }\end{array}$ & $\begin{array}{l}\text { Fertilizer and } \\
\text { Petrochemical }\end{array}$ & Electricity & Industry & $\begin{array}{c}\text { Export / } \\
\text { LNG } \\
\text { Commitment }\end{array}$ & Total Supply \\
\hline 2018 & 80,15 & 25,60 & 472,50 & 72,75 & 45,00 & 987,00 & 1683,00 \\
\hline 2019 & & & & & & & 1690,00 \\
\hline 2020 & & & & & & & 1600,00 \\
\hline 2021 & & & & & & & 1300,00 \\
\hline 2022 & 132,84 & 31,12 & 472,50 & 86,47 & 145,00 & 492,00 & 1359,93 \\
\hline 2023 & & & & & & & 1200,00 \\
\hline 2024 & & & & & & & 1040,00 \\
\hline 2025 & & & & & & & 1150,00 \\
\hline 2026 & & & & & & & 1100,00 \\
\hline 2027 & 82,73 & 39,71 & 472,50 & 99,36 & 270,00 & 20,00 & 984,30 \\
\hline
\end{tabular}

\section{METHODS}

Figure 1 shows the scheme of methodology which was done in this research. It is start from literature study of the route selection case. Route selection consists of several aspects to consider. Due to many aspects to be considered, route selection should include some objectives to be an optimized solution. Multicriteria optimization is the next issue to be studied. Based on the aspects, mathematical model to be developed. The model should indicate the case, which is the optimization of multicriteria problems. The specific data for the case was collected from various reliable sources. Once, they are collected, the data should be processed. The spatial data were processed by using reliable Geographical Information System (GIS)processing software. The compiled data was arranged in matrix format in spreadsheets for easier taken for the software programming. 


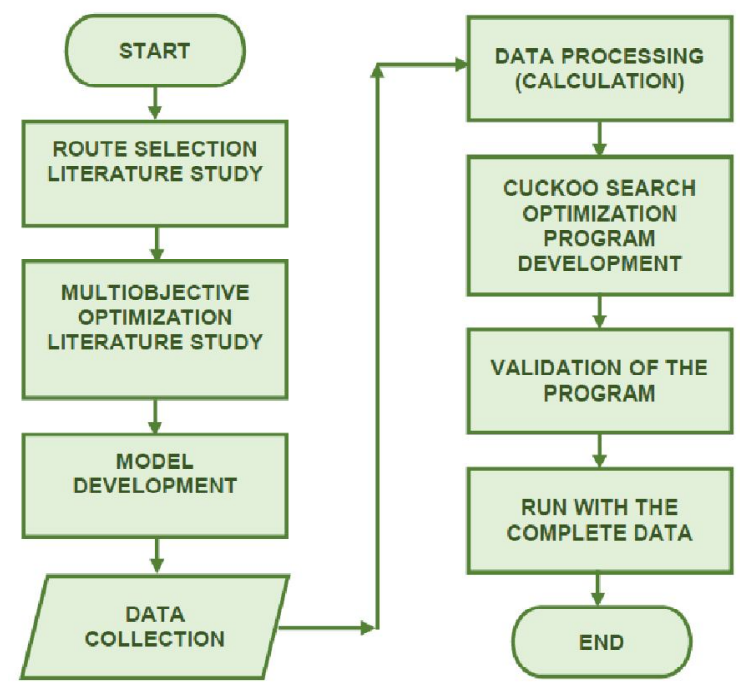

Figure 1:Scheme of methodology

\subsection{Mathematical Modelling}

The mathematical model which contains variables in route selection are shown as follow:

\section{Goal Constraints:}

1. Total Pipeline Length, in km:

$\sum_{i=1}^{m} \sum_{j=1}^{n} L_{i j} x_{i j}-d_{1}^{+}=1,210$

2. Total Pipeline Cost, in millions USD:

$\sum_{i=1}^{m} \sum_{j=1}^{n} C_{i j} x_{i j}-d_{2}^{+}=1,355$

3. Total $\mathrm{CO}_{2}$ emission, in ton $\mathrm{CO}_{2}$ per year:

$\sum_{i=1}^{m} \sum_{j=1}^{n} E_{i j} x_{i j}-d_{3}^{+}=60,000$

4. Total Conservation Area, in $\mathrm{km}^{2}$ :

$\sum_{i=1}^{m} \sum_{j=1}^{n} A V_{i j} x_{i j}-d_{4}^{+}=1$

5. Total Population, in peoples

$\sum_{i=1}^{m} \sum_{j=1}^{n} N_{i j} x_{i j}+d_{5}^{-}=1,000,000$

\section{Hard Constraint:}

6. Total Pressure Drop, in psi

$\sum_{i=1}^{m} \sum_{j=1}^{n} P D_{i j} x_{i j} \leq 600$

$x_{i j}=1$ if the route is selected

$x_{i j}=0$, if others

$i=1,2,3, \ldots, m$

$j=1,2,3, \ldots, n$

$d_{k}^{-}, d_{k}^{+}>0, \mathrm{k}=1,2,3$

\section{Data}

Supply and demand of natural gas in Kalimantan is based to Indonesian Ministry of Energy and Mineral Resources report. Estimation of the gas flowrate, based om the data, is 300 MMscfd, that will be used as basis for this study.Geographical Information System provides data which are required in this study, such as: (1) administrative regencies/districts/sub-districts, (2) settlement of population, (3) river, lake, and other water body, (4) peatland areas (5) conservation areas, etc. Data were retrieved from some authorized websites, http://tanahair.indonesia.go.id and http://geoportal.menlhk.go.id. The raw data are processed by using Quantum GIS Software, version 3.6. Noussa. By using the software some information can be shown and interpreted easier. Population data are collected from data of Badan Pusat Statistik (BPS) for each district.

\subsection{Calculation Isothermal fluid flow}

Some formula is commonly used in oil and gas pipeline application when considering the flowing fluid is in Isothermal condition. Panhandle A formula is used for natural gas pipelines and it is applicable for partially turbulent (hydraulically smooth) flow. Panhandle B formula is used for long transmission lines and applicable for fully turbulent flow. Weymouth formula is used for sizing gas pipelines and applicable for fully turbulent flow [10]. In this study, the pipe size estimation usingthe Panhandle A formula, which is shown on equation below [10],

$q^{\prime}{ }_{h}=18.161 E\left(\frac{T_{b}}{P_{b}}\right)^{1.0788}\left[\frac{\left(P_{1}\right)^{2}-\left(P_{\prime_{1}}\right)^{2}}{L_{m} T_{\text {avg }} S_{g}^{0.8539}}\right]^{0.5} d^{2.6182}$

where,

$\mathrm{d} \quad=$ internal diameter (in)

$\mathrm{E} \quad=$ efficiency factor (unitless)

$\mathrm{L}_{\mathrm{m}} \quad=$ length of pipe $(\mathrm{ft})$

$\mathrm{P}^{\prime}{ }_{\mathrm{b}}=$ absolute pressure at standard conditions $=14.7 \mathrm{psia}$

$\mathrm{q}^{\prime}{ }_{\mathrm{h}}=$ rate of flow at standard condition (14.7 psia and $60^{\circ} \mathrm{F}$ ) in millions of cubic feet perday (MMscfd)

$\mathrm{S}_{\mathrm{g}} \quad$ = specific gravity of gas relative to air $=$ the ratio

$\mathrm{T}_{\mathrm{avg}}=$ average temperature $\left({ }^{\circ} \mathrm{R}\right)$

$\mathrm{T}_{\mathrm{b}}=$ absolute temperature at standard condition $=520^{\circ} \mathrm{R}$

Pressure drop becomes the main concern or limitation in pipeline sizing, since the pressure should not drop drastically along the pipeline. Calculation result for the size was 32".

\section{Cost estimation}

Inflation is considered in cost estimation, the equation used is as follow [11]:

$C(y)=D A m e^{i(y-1980)}$

where,

$\mathrm{C}(\mathrm{y})=$ cost of the pipe in year $\mathrm{y}$

$\mathrm{D}=$ diameter pipeline in inch

A = average cost of pipeline construction per inch-

diameter-mile

$\mathrm{m}=$ length of pipelines in miles

$\mathrm{i}=$ continuously compounded rate of inflation

$\mathrm{y}=$ year of which the cost estimate is desired

There are four cost components which are commonly used. They are right of way (ROW), material, labor, and miscellaneous [11]). Other cost related items, can be categorized or included into one of those components. Location factor was considered since many cost references are from United States of America (USA). The location factor for South-East Asia is 0.8 of USA/Canada [12]. 
Soufyan Maliki et al., International Journal of Emerging Trends in Engineering Research, 8(9), September 2020, 5598 - 5602

\section{$\mathrm{CO}_{2}$ emission}

To estimate the amount of $\mathrm{CO}_{2}$ emission to atmosphere, below equation is used [13]):

$$
\mathrm{CO}_{2} \text { emission }=L U_{\text {Area }} \times D_{\text {Area }} \times D_{\text {Depth }} \times \mathrm{CO}_{2_{1 m}}[t / y]
$$

Where,

LU_Area $=$ peatland area with specific land use [ha]

D_Area = drained area within peatland area with specific land use [fraction]

D_Depth = average groundwater depth in drained peatland area with specific land use [m]

$\mathrm{CO}_{2} \_1 \mathrm{~m}=\mathrm{CO}_{2}$ emission at an average groundwater depth of $1 \mathrm{~m}=91\left[\mathrm{t} \mathrm{CO}_{2}\right.$ ha $\left.^{-1} \mathrm{y}^{-1}\right]$

\section{Cuckoo Search for Optimization of Route Selection}

CS is a kind of swarm-intelligence-based algorithm. [14] developed this algorithm, when inspired by natural behavior of cuckoos. Some cuckoo birds do a kind of brood parasitism by putting their eggs in the nests of other host birds. There are three rules which was defined by Yang and Deb for implementing this algorithm as an computer algorithm:

- Each cuckoo puts one egg at a time, and dumps the egg in a nest which is randomly chosen.

- The best nests with high-quality eggs will be carried over to the next generations.

- The number of available host nests is fixed and the egg put by a cuckoo may befound by the host bird with a probability pa $\in(0,1)$. In this case, the host bird can either get rid of the egg, or simply abandon the nest and build a completely new nest.
Some researchers did comparison of this algorithm performance with DE Algorithm performance, particle swarm optimization and simulated annealing. Cuckoo search can be characterized by three features as follow:

- it satisfies the requirement of global convergence

- it supports the capabilities of local and global search

- it uses Lévy flights as a global search strategy.

The original CS was firstly tested using numerical function optimization benchmarks. Usually, this kind of problems presents a test bed for new developed algorithms. In line with this, standard benchmark function suites [14] have been developed in order to make comparison between algorithms as fair as possible. Multi-objective optimization is methods to handle more than one objective, and these objectives may not be sufficiently solved. Solution for the problem with many criteria are real-world optimization problems.Multi-objective optimization algorithms require a set of many (potentially infinite), optimal solutions, named Pareto front in [15], and [16].

\section{RESULTS AND DISCUSSION}

Selected route by using cuckoo algorithm is indicated in Figure2.The figure shows that the route is not the shortest one. The route is started from Point 1, Siantan District, where the gas pipeline from offshore (Natuna Island) is landed. Siantan district is near Pontianak, the capital of Kalimantan Barat Province.The peatland area in Kalimantan Tengah located in large area around Point 7 and Point 8, Pulau Hanaut District and Sebangau District. The optimization try to avoid the peatland and conservation area as much as possible. The end point is Mekar Sari District which is located near Banjarmasin, the capital of Kalimantan Selatan Province.

Table 3: Optimization result using cuckoo search.

\begin{tabular}{clcccccc}
\hline Route & \multicolumn{1}{c}{ Description } & $\begin{array}{c}\text { Length } \\
(\mathbf{k m})\end{array}$ & $\begin{array}{c}\text { Cost } \\
(\mathbf{U S D})\end{array}$ & $\begin{array}{c}\text { CO2 } \\
\mathbf{e m i s s i o n} \\
(\mathbf{t} / \mathbf{y})\end{array}$ & $\begin{array}{c}\text { Conservation } \\
\text { Area } \\
(\mathbf{k m 2})\end{array}$ & $\begin{array}{c}\text { Population } \\
\text { Pressure }\end{array}$ & $\begin{array}{c}\text { Pressur } \\
\text { Drop } \\
(\mathbf{p s i})\end{array}$ \\
\hline $1 \rightarrow 2$ & $\begin{array}{l}\text { Siantan } \rightarrow \text { Nanga } \\
\text { Tayap }\end{array}$ & 237.20 & $235,390,696$ & 34,702 & 0.48 & 624,353 & 75.37 \\
$2 \rightarrow 4$ & $\begin{array}{l}\text { Nanga Tayap } \rightarrow \\
\text { Belantikan Raya }\end{array}$ & 90.25 & $89,564,950$ & - & - & 153,547 & 30.04 \\
$4 \rightarrow 5$ & $\begin{array}{l}\text { Belantikan Raya } \rightarrow \\
\text { Arut Selatan }\end{array}$ & 114.89 & $114,017,105$ & 2,765 & - & 164,596 & 42.45 \\
$5 \rightarrow 6$ & $\begin{array}{l}\text { Arut Selatan } \rightarrow \text { Petak } \\
\text { Malai }\end{array}$ & 227.57 & $225,831,134$ & - & - & 109,662 & 93.57 \\
$6 \rightarrow 9$ & $\begin{array}{l}\text { Petak Malai } \rightarrow \\
\text { Mantangai }\end{array}$ & 114.89 & $114,017,105$ & 2,765 & - & 164,596 & 42.45 \\
$9 \rightarrow 10$ & $\begin{array}{l}\text { Mantangai } \rightarrow \text { Mekar } \\
\text { Sari }\end{array}$ & 227.57 & $225,831,134$ & - & - & 109,662 & 93.57 \\
& Total & $\mathbf{1 1 4 . 8 9}$ & $\mathbf{1 1 4 , 0 1 7 , 1 0 5}$ & $\mathbf{2 , 7 6 5}$ & - & $\mathbf{1 6 4 , 5 9 6}$ & $\mathbf{4 2 . 4 5}$ \\
\hline
\end{tabular}

The criteria of environment and population have effect to the result of the route selection. Firstly, the shortest route is selected as the basis for comparison purpose. The shortest route has length and cost estimation, $810 \mathrm{~km}$ and $760,789,510$ USD respectively. By goal programming, the length and cost are proposed as $1020,72 \mathrm{~km}$ and $1,012,934,497$ USD, respectively. Estimated emission of
$\mathrm{CO}_{2}$ to atmosphere is, 60,532ton $\mathrm{CO}_{2} /$ year, which is $35 \%$ smaller than the shortest route. Impacted Conservation area is $0,63 \mathrm{~km}^{2}$, which is $65 \%$ smaller than the shortest route. Population near the pipeline route indicates one of social aspects. It is considered, that potentially the population will use gas as the main energy source. The government may decide to develop another project of gas city network to 
utilize the gas in the city or region. Population near the route of pipeline is $1,274,661$ people, which is $72 \%$ higher than the shortest route. Total Pressure drop across the pipeline will be 422 psi. It higher $48 \%$ from the shortest route. The longer pipe will have the higher total pressure drop. But, it is still lower the target, therefore we can use this margin to havethe optimum result considering overall aspects.

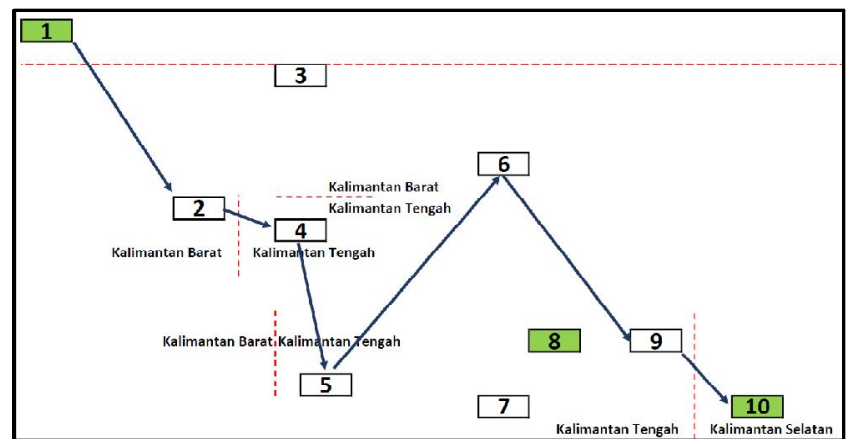

Figure 2:Selected route using cuckoo search algorithm

\section{ACKNOWLEDGEMENT}

This study has been supported partially by PITTA 2019 Grant funded by DRPM Universitas Indonesia under contract No.: NKB-0732/UN2.R3.1/HKP.05.00/2019.

\section{REFERENCES}

1. Baeza, D., Ihle, C.F., and Ortiz, J.M. (2017). A comparison between ACO and Dijkstra algorithms for optimal ore concentrate pipeline routing. Journal of Cleaner Production, 144, 149-160. doi:https://doi.org/10.1016/j.promfg.2019.02.125

2. Crane (2013). Flow of fluids through valves, fitting, and pipe, Technical Paper No. 410, 1-9.

3. De Lucena, R,R, Baioco, J.S., de Lima, B.S.L.P., Albretch, C.H., and Jacob, B.P. (2014). Optimal design of submarine pipeline routes by genetic algorithm with different constraint handling techniques. Advances in Engineering $\quad$ Software, $76 . \quad 110$ 124.doi:https://doi.org/10.1016/j.advengsoft.2014.06.0 03

4. Hooijer, A., Page, S., Canadell, J.G., Silvius, M., Kwadijk, J., Wosten, H., and Jauhiainen, J. (2010). Current and future $\mathrm{CO} 2$ emissions from drained peatlands in Southeast Asia. Biogeosciences, 7, 15051514.doi:10.5194/bgd-6-7207-2009

5. IEA, Transmission of CO2 and energy. (2002).IEA Greenhouse Gas R\&D Programme, Report no. PH4/6.

6. Joosten, $\mathrm{H}$. (2010), The global peatland $\mathrm{CO}_{2}$ picture: peatland status and drainage related emissions in all countries of the world. Wetlands International.

7. https://unfccc.int/sites/default/files/draftpeatlandco2rep ort.pdf

8. Kang, J.Y. \& Lee, B.S. (2017). Optimization of pipeline route in the presence of obstacles based on a least cost path algorithm and laplacian smoothing. International Journal of Naval Architecture and Ocean Engineering, 9.492498.doi:https://doi.org/10.1016/j.ijnaoe.2017.02.001
9. Marcoulaki, E.C., Papazoglu, I.A., and Pixopoulou, N. (2012). Integrated framework for the design of pipeline systems using stochastic optimisation and GIS tools. Chemical Engineering Research and Design, 90, 22092222.doi:https://doi.org/10.1016/j.cherd.2012.05.012

10. Mohitpour, M., Szebo, J. and Hardeveld, T.V. (2000), Pipeline Design and Construction. ASME Press. New York., 23.

11. McAllister, E.W., Pipeline Rules of Thumbs Handbook 7th ed. (2009). Gulf Professional Publishing, 635-689.

12. Robič, T. and Filipič, B. (2005). Demo: differential evolution for multiobjective optimization, in Evolutionary Multi-Criterion Optimization. Lecture Notes in Computer Science, Vol. 3410, 520-533, Springer.

13. Taha, H.A. Operation Research an Introduction, 8th ed. (2007). Pearson Prentice Hall, 329-344.

14. Veldhuizen, D.A.V. and Lamont, G.B. (2000). Multiobjective evolutionary algorithms: analyzing the state-of-the-art. Evolutionary Computation, Vol. 8, No. 2, 125-147.

15. Wang, F., He, X-S., Wang, Y. and Yang, S-M. (2012). Markov model and convergence analysis based on cuckoo search algorithm. Jisuanji Gongcheng/Computer Engineering, Vol. 38,No. 11, 80-185.

16. Yang, X-S. and Deb, S. (2009). Cuckoo search via Lévy flights, World Congress on Nature \& Biologically Inspired Computing, 2009. NaBIC 2009, IEEE, 210 214.doi:10.1109/NABIC.2009.5393690

17. Yang, X-S. and Deb, S. (2010). Engineering optimization by cuckoo search. International Journal of Mathematical Modelling and Numerical Optimization, Vol. 1, No. 4, 330343.doi:10.1504/IJMMNO.2010.035430

18. Yildrim, V., et al (2016). A spatial multicriteria decision-making method for natural gas transmission pipeline routing. Structure and Infrastructure Engineering.doi:10.1080/15732479.2016.1173071

19. Zhou, J., Liang, G., Deng, T., and Gong, J. (2017). Route optimization of pipeline in gas-liquid two-phase flow based on genetic algorithm.Hindawi International Journal of Chemical Engineering, Article ID 1640303.doi:https://doi.org/10.1155/2017/1640303.

20. E. Ahmed and H. M. Abduljalil, "Effect of NH2 substituent group on PC61BM properties using DFT," Int. J. Emerg. Trends Eng. Res., vol. 7, no. 8, pp. 183190, 2019.

21. S. Chatterjee, "3D Modeling \& Numerical Simulation of Heat transfer of Back-pack Thermoelectric," Int. J. Emerg. Trends Eng. Res., vol. 6, no. 8, pp. 53-61, 2018. 